\title{
THE TRANS-DISCIPLINARY GLOBALIZATION DEBATES OVER THE LAST TWO DECADES: SMALL CONSENSUS, BIG CONTROVERSIES
}

\author{
Hoyoon Jung
}

\begin{abstract}
The term 'globalization' has become a buzzword in our contemporary era. Globalization has thus caught a particular scholarly attention throughout the last two decades, yielding heated debates across a wide range of academic disciplines, particularly in the social sciences. The primary aim of this research is to characterize the key transdisciplinary academic debates of globalization that have arisen in the social sciences over the last two decades. Particular attention will be paid to the varied definitions, dimensions, perspectives and dynamics of globalization. By reviewing and analyzing a vast array of academic literature on globalization, this study finally suggests that due to the concept's inherent complex, multifaceted and multidimensional nature, this notion has gained a relatively small consensus and big controversies.
\end{abstract}

Keywords: globalization, consensus, controversies.

\section{Introduction}

According to Jan Art Scholte (1995), 'globalization stands out for quite a large public spread across the world as one of the defining terms of late twentieth-century social consciousness.' Therefore it would not be a hyperbole to say that globalization has indeed become a buzzword of our times, appearing as the primary attractor of everyday conversations, books, and articles (Kellner 2002; Steger 2009, 2014). Globalization has thus caught a particular scholarly attention throughout the last two decades, yielding heated debates across a wide range of academic disciplines. As Pieterse (2015: 8-9) points out, globalization debates have invited more controversies than consensus; the former being more pronounced in comparison to the latter. Controversies on globalization are, in brief: What is globalization and does it really exist? Is globalization multi-dimensional or solely confined to an economic phenomenon that can be objectively or quantitatively testified by statistical measures? Is globalization neoliberal capitalism? Does globalization lead to cultural conflict, homogeneity or hybridity? and many others (Pieterse 2015). In this regard, this paper aims to explore the key debates of globalization that have arisen in the social sciences. To be specific, by reviewing and analyzing a vast array of literature on globalization, I will navigate the varied definitions, dimensions, perspectives and dynamics of globalization in the following chapters.

Journal of Globalization Studies, Vol. 9 No. 2, November 2018 18-31 DOI: $10.30884 / j o g s / 2018.02 .02$ 


\section{Conceptualizing Globalization: Definitions and Dynamics of Globalization}

Globalization as a conceptual framework began to permeate a growing body of social sciences literature from the 1980s. However, these popular usages and the diverse conceptualizations of the term have led to the concept conveying multiple meanings (McGrew 1990). For some scholars, globalization signifies the acceleration of interconnectedness. For example, according to McGrew (1990: 470), globalization constitutes a 'multiplicity of linkages and interconnections that transcend nation-states (and by implication the societies) which make up the modern world system.' For others, the conceptual framework of globalization should involve not only the objective process of interconnection but incorporate the cognitive domains as well. In this context, Robertson (1992: 8) refers to globalization as 'the compression of the world and the intensification of consciousness of the world as a whole.' In very concise but more compelling manner, Steger (2014: 1490) defines globalization as 'the expansion, intensification and acceleration of social relations and consciousness across world-time and world-space.' In his path-breaking study on globalisms, Steger specifically urges that we need to make a conceptual distinction between globalism and globalization although the former cannot exist in isolation from the latter. For him, the concept of globalism not only provides a less conventional - but critical - lens to particularly look at ideological and discursive dimensions of globalization, but also a way by which we can grasp the formidable role of ideas, beliefs, language, and symbols in shaping the social conditions (Steger 2009: 17-18).

Some scholars have attempted to link globalization with fundamental transformations in our everyday experience of time and space. In his theory of global capitalism, David Harvey (1990) conceptualizes globalization as ‘time-space compression' by suggesting that flexile accumulation of today's capitalism - accelerating the process of economic activities and capital movements by mean of technological developments has dismantled the barriers of time and space across the world. Meanwhile, Anthony Giddens (1990) suggests that the level of 'time-space distanciation' in our modern time is incommensurable with any previous era, arguing that:

The relationship between local and distant social forms and events become correspondingly 'stretched.' Globalization refers essentially to that stretching process, in so far as the modes of connection between different social contexts or regions become networked across the earth's surface as a whole. Globalization can thus be defined as the intensification of worldwide social relations which link distant localities in such a way that local happenings are shaped by events occurring many miles away and vice versa (Giddens 1990: 64).

Thus, for Giddens, 'time-space distanciation' refers to the stretching of social relations between great distances and local contextualities. In spite of some differences in substance, both theories of 'time-space compression' and 'time-space distanciation' share the assumption in common that there occurs the reorganization and recomposition of time and space as a core feature of globalization.

Ordóñez and Sánchez (2016) assume globalization as an essentially spatial concept. Based on the concept of the global geography of capital and Gramscian hegemony, they analyzed how the two hegemonic projects - the neoliberal project and the Global South - have struggled for a global supranational supremacy. For the authors, globalization thus refers to an open process, 'which is actually and will be the result of different forms of re-articulation and re-hierarchization of spatial scales, depending on the hege- 
monic projects that prevail in the actual global struggle’ (Ordóñez and Sánchez 2016: 4). Similarly, Pieterse (2017) sees the current state of globalization in the twenty-first century primarily as a 'multipolar world' and analyzes how this multipolarity has been reshaping globalization in modern times. The sharp growth of Asia - particularly the rise of China - and Global South economies have, according to Pieterse, led to the new formation of global geography and a momentous change of the power structure in the world order.

In some studies, globalization is understood as the result of global structureoriented process. In this context, world polity theorists - the so called Stanford school of global analysis - grasp globalization in ways that 'the modern world society causes the diffusion of common institutional models and patterns of legitimacy among nation states,' such as democracy, educational system, women's rights, markets and so on (Burawoy 2000: 2). Likewise, based on sociological institutionalist tenets, Meyer and his associates argue that 'world society models shapes nation-state identities, structures, and behavior via worldwide cultural and associational processes' (Meyer et al. 1997: 144, 173). Through consistent empirical studies, they succeeded in showing how the rise of cultural and institutional isomorphism among the nation-state has been empowered by the world society model (Ramirez et al. 1997; Kim and Sharman 2014). Meanwhile, for other scholars, globalization is essentially the consequence of modernity. Giddens (1990) basically assumes globalization as an unprecedented high modernity, extended across the globe. Based on his analysis of institutional dimensions of modernity consisting of surveillance, military power, industrialism and capitalism, he outlines the dimensions of globalization as world capitalist economy, nation-state system, world military order and international division of labor respectively. However, the problem here on two abovementioned accounts - world polity and modernity approaches to globalization - is that both are too Eurocentric. Without a doubt, world polity theorists focus exclusively on how actually 'Western' society models diffuse 'Western' cultural and institutional values to 'the Rest.' Pieterse (2015), in addition, criticized the modernity/globalization approach primarily because it is not about globalization, but Westernization, by specifically maintaining as follows:

There are several problems associated with the modernity/globalization approach. In either conceptualization, whether centered on capitalism or modernity, globalization begins in and emanates from Europe and the West. In effect, it is a theory of westernization by another name, which replicates all the problems associated with Eurocentrism... While modernization theory is a passed station in sociology and development theory it is making a comeback under the name of globalization - the 1950s and 1960s revisited under a wide global umbrella (Pieterse 2015: 69).

For Manuel Castells (1996, 1997, 1998, 2000, 2003), globalization can be described as 'network society' grounded in and empowered primarily by completely new information and communication technology. Specifically, he argues that a network society promoted by information technology is the arena in which 'the space of flows - flows of information, technology, and finance - replaces the space of places, the rootedness of industrial work, the fixity of urban and rural life' (Castells 1996: 1; cited in Burawoy 2000: 2). However, these accounts have also been accused of its technological determinist premise. According to Pieterse (2015: 10), technology itself is 'socially embed- 
ded and shaped'; thus, for him, 'what matters is not technology per se but the way it is harnessed by economic, political and social forces.'

Based on the historical materialist view, William Robinson (2004) characterizes globalization as 'epochal change in world capitalism.' He specifically points out that political, cultural and other dimensions of globalization are structurally determined by the rise of global economy, by claiming:

We believe that studying the nature and dynamics of the capitalist system, how it has evolved historically, and how it is changing currently will give us the key to understanding globalization. Stated in more academic terms, the global capitalism school believes that globalization can be explained largely by a methodologically prior, materialist theory of capitalism... Most social scientists agree that globalization is a multidimensional process involving complex changes at many different levels, including economic, political, and cultural levels. There is much less agreement on how to order these dimensions or whether there is an underlying determinacy. Sociologists such as Malcolm Waters and Roland Robertson ultimately see ideas as the driving force in globalization... In contrast, my conception of globalization, broadly consistent with the global capitalism school, sees the rise of a global economy as structurally determinant (Robinson 2004: 2, 9-10).

Put simply, Robinson asserts that both technology and cultural globalization cannot be separated from capitalist globalization, rather the latter produces 'concomitant process' of the former as dependent variables.

James N. Rosenau's (1997) delineation of globalization as 'fragmegration,' a compound word of fragmentation and integration, offers niche insights as well. In his book Along the Domestic-Foreign Frontier, Rosenau argues that simultaneous occurrence of globalizing and localizing forces and ensuing 'fragmegrative dynamics' made the division of domestic/foreign boundary meaningless in our turbulent and complex times. Similarly, Roland Robertson (1995) puts forward 'glocalization' thesis, which disputes an evident tendency to understand globalization as all-encompassing large-scale phenomena. According to him, this macro-sociological perspective significantly neglects the local dynamics, rendering the global as antithetical to the local; rather, 'what is often referred to as the local is essentially included within the global' (Robertson 1995: 35). Therefore, for Robertson, there can be no global without the local. Meanwhile, Saskia Sassen's $(2003,2006)$ articulation of globalization is also particularly noteworthy in that her thesis provides novel spatial dimensions of the national and the global. Sassen's principal assumption is that globalization should be understood in the context of two sets of dynamics. While one of these is explicitly global in scale - such as the formation of global processes and institutions, the other set of processes does not necessarily take place at the global level but happens 'deep inside territories and institutional domains that have largely constructed in national terms in much, though by no means all, of the world.' According to her, the latter dynamics can be considered an integral part of globalization precisely because 'they involve transboundary networks and formations connecting multiple local or "national” processes and actors' (Sassen 2003: 1-2). In this context, Sassen maintains that 'specific structurations of what we have represented as the global are actually located deep inside state institutions and national territories.' In turn, 'what has been represented as the scale of the national contains a simultaneity of power relations, some pertaining to the national and others to the global' (Ibid.: 14). 


\section{Varied Perspectives of Globalization}

Just as there are a huge number of interpretations of globalization, perspectives of globalization differ greatly as well, depending on the lens through which scholars see this phenomenon. Mittleman (2000: 3-4), by examining the emerging globalization debates within the field of international relations, categorizes those perspectives into 'parakeepers' and 'para-makers.' According to him, para-keepers are naysayers 'who doubt or deny that globalization constitute an ascendant paradigm' such as neorealists (Waltz 1999), neoliberal institutionalists (Keohane and Nye 2000) as well as world-systems theorists such as Wallerstein (2000). Keohane and Nye (2000: 104) maintained that globalization is not entirely a novel phenomenon, arguing that 'our characterization of interdependence more than 20 years ago now applies to globalization at the turn of the millennium.' In contrast, para-makers are 'those who bring into question what they regard as outmoded categories and claims to have shifted to an innovatory paradigm, namely globalization' (Mittelman 2000: 1-5). In this regard, Cerny (1996) maintains that the concept of globalization can be the chief contender for the long-lasting honor of realist school of thought.

While acknowledging that Mittleman's categorization of perspectives of globalization is useful, I suggest it has inherent limitations as well, because the growing debates of globalization have not been confined solely to the international relations discipline. Steger $(2009,2014)$ in this regard suggests broader but detailed classification of perspectives of globalization that incorporates a wide range of academic disciplines - rejectionists, skeptics, modifiers and globalizers. While the first three basically assumes that globalization is 'globaloney', the last one sees globalization as a completely transformative set of processes that guide our everyday lives.

\section{Rejectionist}

Rejectionists maintain that existing scholarly accounts of globalization are imprecise and even exaggerated. Thus, they contradict the usefulness and validity of globalization as an analytical concept (Steger 2009, 2014). For example, Susan Strange (1996, Preface) refers to globalization as 'anything from the Internet to a hamburger.' Similarly, Linda Weiss (1998: 212) relegates globalization to 'a big idea resting on slim foundations.' Likewise, Wallerstein (2000: 28) mentions 'personally I think it [globalization] is meaningless as an analytical concept and serves primarily as a term of political exhortation.' All three share interpretations in common that globalization is, analytically, a vacuous term.

\section{Skeptics}

While skeptics acknowledge that there exist some manifestations and forms of globalization, they nevertheless underline the limited nature of current globalizing processes (Steger 2014). Skeptics primarily point out that 'the world is not as nearly integrated as many globalization proponents believe' (Steger 2009: 24). Hirst and Thompson (1996) also demonstrate that a majority of international flows of trade, direct investment, capital and portfolio are mostly confined within the advanced countries and regions rather than spread across the world. They also assert that multinational corporations are not borderless institutions; rather they are still deeply embedded in their nation-state with regard to the share of overall activities. In this regard, they claim that 'globalization in its radical sense should denote the development of a completely new economic structure, not just conjectural changes toward an increased international trade and investments' (Hirst and Thompson 1999: 7). In a similar vein, Kenneth Waltz (1999) points 
out that contemporary world economy is not nearly integrated but merely interdependdent because major parts of the world - Africa, Latin America, Middle East and the most parts of Asia - have been left behind in the process of globalization. Likewise, skeptics have focused mainly on the economic dimension of globalization to show the limited nature of globalization. The main drawback of skeptics' thesis can be found here. Given that globalization is a set of multidimensional processes, skeptics obviously ignore areas other than the economic realm; for example, spheres such as the political and cultural dimensions of globalization.

\section{Modifiers}

Modifiers are critics of globalization who disagree with the understanding that this process is a recent and novel phenomenon. Pointing out that the term globalization has been understood in a historically incorrect manner, they maintain that globalizers who believe that globalization is a new process are significantly devoured by their shortsighted historical framework (Steger 2009, 2014). Hirst and Thompson, who were regarded as skeptics in the previous section, are considered at the same time as modifiers. They argue that large international flows such as trade, direct investment and migration are nothing new; rather the beginning of twentieth century witnessed a similar intensity of transactions across borders (Hirst and Thompson 1996). Similarly, Robert Gilpin (2001) contends that:

Globalization has been the defining feature of the international economy at the beginning of the twenty-first century, the extent and significance of economic globalization have been greatly exaggerated and misunderstood in both public and professional discussions; globalization in fact is not nearly as extensive nor as sweeping in its consequences as many contemporary observers believe. This is still a world where national policies and domestic economies are the principal determinants of economic affairs. Globalization and increasing economic interdependence among national economies are indeed very important; yet, as Vincent Cable of the Royal Institute of International Affairs has pointed out, the major economic achievement of the post-World War II has been to restore the level of international economic integration that existed prior to World War I (Gilpin, R., and Gilpin, J. M. 2001: 3).

Gilpin's perspective shows noticeable convergence with Hirst and Thompson's argument in that they postulate an inception of globalization more than a century ago. Meanwhile, some world system theorists (Arrighi 1994; Chase-Dunn 1998) insist that the expansion and the acceleration of modern capitalism and the European system have besieged the globe over the past five centuries. In spite of disagreements among scholars with regards to the starting point of globalization, modifiers all dispute the novelty of the globalizing process in common.

\section{Globalizers}

Globalizers or so-called radicals firmly believe that globalization is 'a profoundly transformative set of social processes that is moving us into a new chapter of human history' (Steger 2014: 1493). The proponents of this perspective share common conviction that globalization is empirically 'real' and truly 'global' in terms of its reach and impact. Refuting an idea that globalization is just a single monolithic process, they argue that it is indeed a complex and uneven set of processes (Ibid.). Globalizers have generally clustered around under the umbrella of economic, political and cultural globalization theses respectively. 


\section{Main Dimensions of Globalization}

Globalization as Economic Process

Many scholars, mostly economists, tend to view that the expansion and acceleration of economic activities across the globe is the primary aspect of globalization. According to Steger (2009: 29), they believe that globalization studies should follow the tradition of social scientific research and the central research task should be the minute scrutinization of the evolving structure of global financial markets and international economic institutions. Therefore, globalizers - in the economic globalization perspective - maintain that trade, financial statistics, capital movements, investment and many other types of global economic activities truly constitute 'objective' and 'real' globalization which signals epochal transformations, while relegating all the rest as fantasy or myth (Steger 2009; Pieterse 2015). Jagdish Bhagwati, in this sense, argues that globalization constitutes 'the integration of national economies in global economy, through trade, foreign direct investments, short-term capital flows, international flows of workers and humanity generally, and flows of technology' (Bhagwati 2007: 3). Apart from the fact that the global economic activities, international financial markets and institutions mark an important aspect of economic globalization, one should also recognize the rise of Transnational Corporations (TNCs) and their role in changing the map of global production. TNCs also bypass national or domestic political influences of worker's organizations and trade unions (Steger 2009); moreover, they transnationally move their base in search of better profits and a favorable tax regime. Neubauer (2014: 267) notes in this context that 'global corporations are inseparable from the more general phenomenon of globalization itself.'

However, it is widely recognized that several problems have been yielded by the proponents of economic globalization thesis. On the one hand, they significantly overlook the subjective dimensions of the process in globalization research. In this sense, Steger (Steger and James 2013) asserts that globalization not only involves the objective intensification of social relations across the globe, but also includes subjective ideas, meanings, sensibilities and understandings in relation to those material processes of extension, urging more close examination of ideological dimensions - globalisms - expressing the global imaginary. On the other hand, these proponents, mostly economists, are in favor of capitalist or neoliberal globalization in general. - In a thorough study regarding the current state of capitalist globalization, Milanovic (2016) suggests 'winner-take-all' as one of the major characteristics of current globalization, and argues that capitalist globalization deepens inequality not only within countries, but also among countries, along with the rise of global plutocrats. On top of that, Hart-Landsberg (2015), a critical economist, criticizes saying most economists share a strong consensus that capitalist globalization is a 'powerful engine of social progress.' For Hart-Landsberg, however, this tendency not only legitimizes the indiscreet movement of capital across the borders promoted by state and corporations but also incapacitates people for the challenge and resistance against this runaway capitalist globalization (Ibid.: 1).

Globalization as Political Process

A majority of the political globalization debates are formed around the extent to which globalization has had an influence on the existing power of the modern nation-state. In particular, scholarly attention on the relationship between globalization and the fate of nation-state, according to Steger (2009), has produced a growing body of works that examine the issue of state sovereignty (Hardt and Negri 2000; Agnew 2009), the pro- 
spects for global governance (Thakur and Weiss 2015), the increasing impact of global civil society (Kaldor 2003), and non-state actors such as non-governmental or intergovernmental organizations (Young 1989; Mazlish 2006; Thakur and Weiss 2015).

Some scholars have focused on the decreasing power of states and sovereignty. According to Mazlish (2006), the forces of globalization have significantly undermined existing state power. He contends, like Young (1989), that while states remain major actors, power is increasingly transferring to amorphous forces such as TNCs, NGOs, IGOs, communications networks, etc. Similarly, Thakur and Weiss (2015: 147-148) highlights the central role played by global governance as a collective problem-solving arrangement in dealing with threats and challenges that are 'beyond the capacity of a single state to address' such as human rights, global health, environmental as well as financial issues. Hardt and Negri's (2000) account of new postmodern global political order what the authors call 'Empire' also reveals how it undermined the basis of modern politics centered primarily on sovereignty and the nation-state system. In a similar vein, Truevtsev (2016) observes globalization as a political process that fundamentally influences the political structure at the inter-state, regional and international levels in an unprecedented way, particularly disturbing the structure of world order. He further suggests that the current stage of globalization poses new risks to the political structures and systems' status quo, including the unprecedented opportunities and scale of terrorist threats, globally networked forms of cross-border protests or movements, and the fragmentation of the multinational states.

Other scholars emphasize the role of technological development and networks in politics and world affairs. Representatively, Castells (2008) argues that globalization has transformed the character of public sphere from the traditional space of debate on 'national' public affairs to the global debate, accelerating the emergence of global governance and a global civil society constructed around global communication networks. In a similar vein, by illustrating the case of Arab Spring and the resistance campaigns to immigration policy of European countries, Schattle (2012) explores how globalization has accelerated and facilitated these kinds of new political activities. He argues that 'what has changed in the present day are the background conditions of globalization and the digital media age as they accelerate and intensify today's citizen campaigns for civil rights and democracy... Globalization is opening up new forms of political activity and civic engagement, often tied to networks rather than territory' (Schattle 2012: 5). Idowu and Oladiti (2016: 113) illustrate, in this regard, how the Arab Spring in Libya was enabled and promoted by the spread of social media combined with the forces of globalization that constitute 'popular access to a shared source of news and information, located within a common cultural context.'

More remains to be dealt with in terms of the emergence of non-state actor; the recent spread of private military or security corporations (PMCs or PSCs) - accelerated by globalizing processes - seriously threatens state authority (Avant 2005), traditionally regarded as possessing monopoly on the legitimate use of force. Avant (Ibid.) argues that the privatization of force, under the banner of political and economic doctrine of neoliberalism, clearly illustrates how globalizing forces dilute the traditionally takenfor-granted meanings of nation-states.

Globalization as Cultural Process

Roland Robertson (1992) has maintained that culture is truly fundamental to the study of globalization. Likewise, globalizers who place culture at the heart of their research 
claim that any account of globalization would be improper without a close examination of its cultural dimension (Steger 2009). They have focused on the issue of whether globalization triggers cultural conflict, or whether the globalizing forces lead to cultural homogeneity or heterogeneity.

Some scholars maintain that globalization would definitely cause cultural conflict or clash. In his book Jihad vs. McWorld, Benjamin Barber (1996) considers post-Cold War world as the ongoing conflict between global consumerist capitalism and tribal religious fundamentalism. Similarly, Huntington's $(1993,1997)$ theory of clash of civilization also implies how globalization functions as a new engine of cultural conflict. He specifically states that:

A crucial, indeed a central, aspect of what global politics is likely to be in the coming years... It is my hypothesis that the fundamental source of conflict in this new world will not be primarily ideological or primarily economic. The great divisions among humankind and the dominating source of conflict will be cultural. Nation states will remain the most powerful actors in world affairs, but the principal conflicts of global politics will occur between nations and groups of different civilizations. The clash of civilizations will dominate world politics. The fault line between civilizations will be the battle lines of the future (Huntington 1993: 22).

That is, according to Huntington, cultural identities - especially religious identities of people - will become a major source of conflict in the era of globalization.

The most common explanations of globalization, for other scholars, are the idea that 'the world is becoming more uniform and standardized, through a technological, commercial, and cultural synchronization emanating from the West, and that globalization is tied up with modernity' (Pieterse 2015: 67). Therefore, they are concerned with the idea of cultural imperialism which derives from the worldwide diffusion of homogenized, Westernized (Americanized) and consumerist culture (Wagnleitner 1994; Tomlinson 1999). The representative term would be 'Mcdonaldization,' which critical sociologist George Ritzer (1993: 19) refers to as 'the process whereby the principles of the fast-food restaurant are coming to dominate and more sectors of American society as well as the rest of the world.' Another intriguing term would be Coca-colanization which Wagnleitner (1994) describes globalization of American culture, especially in Latin America since the 1970s. In this regard, Mcdonaldization as well as Cocacolanization can be considered as a variation on the theme of cultural imperialism which was fueled by the American media (Pieterse 2015).

The other camp in cultural globalization thesis insists that the globalizing forces bring about the hybridization, or the so-called creolization of culture. Rowe and Schelling (1991) define hybridization as 'the ways in which forms become separated from existing practices and recombine with new forms in new practices' (cited in Pieterse 2015: 72). Specifically, Pieterse (2015), a strong advocate of cultural hybridization thesis, even argues that it will make sense to regard Mcdonaldization as a globally localizing form of ‘intercultural hybridization' by suggesting Shannon Peters Talbott's (1995) studies concerning the case of Mcdonaldization of Mcdonald's in Moscow through an ethnographic study. Talbott concludes in his research that Mcdonalds' in Moscow can be understood as 'global localization' rather than cultural homogenization because Mcdonalds' operations are usually reshaped by a variety of local customs in highly 
mixed forms. In other words, scholars of hybridization believe that cultural homogenization is merely simplistic as culture has not been simply moving toward cultural synchronization. It does not necessarily mean that homogenization thesis is not correct, but that it is fundamentally incomplete. As an example, several local cultures have not only internalized but have also resisted against foreign cultural influences. Moreover, the perspective of cultural homogenization significantly neglects the impact of non-Western culture on the West (Appadurai 1996; Pieterse 2004, 2015). Therefore, while the idea of Mcdonaldization and other examples of McSociety imply the predominance of the global forces and process over the local, hybridization thesis highlights 'the outcome of interactions in which the local appropriates the global' (Delanty 2009).

The Rise of a New Global Landscape? The End of Globalization Debates

The end of the Cold War yielded the emergence of a new pro-market consensus as a dominant position in the global economic governance, disrupting the system of the postwar welfare and regulatory state. It is widely acknowledged, for this reason, that a more economically liberal approach to economic governance is superior and more efficient for the public good. In this regard, many writers and scholars have argued that globalization is indeed the most powerful engine for social good today, if properly governed. For example, in his book, In Defense of Globalization (2007), Bhagwati suggests that globalization is not a societal ill as many critics have argued, but could be a clear solution for the development of human society, through various case studies combined with macroanalysis to form a counter-argument against anti-globalists. Apart from accounts of the merit of globalization, a number of scholars did not leave much room for doubt that globalization itself is in fact unstoppable and irresistible. An illustration is provided by the secretary general of the United Nations, Kofi Annan; globalization is indeed 'a positive force' and, in his words, 'an irreversible process, not an option' (Annan 1999; quoted in Livesey 2017: 3).

However, the recent decades have witnessed a fierce scholarly debate with regards to whether globalization is good or bad, as well as whether it is inevitable. The discontents with traditionally taken-for-granted assumption of globalization and its proponents have coalesced into a strong anti-globalization movement throughout the world as well as intellectual rebellion. Nobel laureate Joseph Stiglitz's (2002) volume Globalization and Its Discontents reveals how 'neoliberal' globalization led by policies of several international financial institutions such as IMF under the banner of privatization, liberalization of trade and financial capital, fundamentally impoverished developing countries and actually caused several economic crises. In his magisterial book, Grave New World: The End of Globalization, the Return of History, King (2017) first points out that the idea that globalization would enhance people's living standard was not true, through his comparative analysis of representative countries' GDP decade by decade. On top of that, the author consistently argues that globalization is not inevitable, but is being increasingly rejected in recent times due to the rise of new nationalism and the pursuit of nationalist agendas that actually promote de-globalization. In a similar vein, Livesey (2017) argues that we are witnessing a dramatic shift from the era of globalization to that of localization, driven by nationalism among many other factors, which has driven tax, trade and regulatory policies to obstruct offshoring.

Whereas King's and Livesey's theoretical explanations fundamentally suggest that the great emphasis on national interests or state-led nationalist agendas have been pro- 
moting the end of the globalization era, other scholars have investigated the emergence of the anti-globalization movement from below. The widening reach of globalization has provoked, in the words of Prempeh (2004: 580), 'a counterhegemonic resistance and political counter-movements that challenge its exclusionary practices and its silencing of the voice of the people,' and this grassroots counterhegemonic process represents civil disobedience against an indiscreet globalization. Rajgopal (2002) examines anti-globalization movements by focusing exclusively on South Asian cases, and argues that this new form of civil disobedience has primarily aimed to counter multinational corporations, calling for just and sustainable development. Aelst and Walgrave (2002) focus on the crucial role played by the new media in the spread of the anti-globalization movement, or more specifically, the anti-neoliberal globalization movement. Meanwhile, using morphological discourse analysis and quantitative analysis based on data collected from more than 40 organizations associated with the World Social Forum, Steger and Wilson (2012) argue that the anti-globalization movement actually should be considered a political 'alter'-ideology, instead of 'anti.' In other words, the current political ideology of the global justice movement needs to be regarded as an alterglobalization movement, according to the authors.

\section{Conclusion: The Future of Globalization Studies}

In this paper, I have sought to explore transdisciplinary academic debates on globalization in the social sciences that have arisen for more than two decades. Due to the concept's inherent complex, multifaceted and multidimensional nature, this notion has gained a relatively small consensus and big controversies. As mentioned earlier, many advocates of economic globalization argue that objectively measurable global economic activities only represent 'real' globalization, and all the rest is mere fantasy (Steger 2009; Pieterse 2015). However, Manfred Steger (2008), a major thinker of globalization, urges that more attention must be paid to the significant role of ideas, ideologies, and languages that constitute the subjective dimension of globalization. Globalization studies should not be confined to being mere observations of objective processes; rather, globalization should also be examined as an ideological practice in the context of a subjective dimension of globalization, which has been significantly understudied. The ideas of globalization are widely studied. Now it is time to study the globalization of ideas.

\section{REFERENCES}

Aelst, P. V., and Walgrave, St. 2002. New Media, New Movements? The Role of the Internet in Shaping the 'Anti-Globalization' Movement. Information, Communication \& Society 5 (4): 465-493.

Agnew, J. A. 2009. Globalization and Sovereignty. Lanham: Rowman \& Littlefield Publishers.

Appadurai, A. 1996. Modernity at Large: Cultural Dimensions of Globalization. Minneapolis: University of Minnesota Press.

Arrighi, G. 1994. The Long Twentieth Century: Money, Power and the Origins of Our Times. London: Verso.

Avant, D. 2005. The Market for Force: The Consequences of Privatizing Security. Cambridge and New York: Cambridge University Press.

Barber, B. R. 1996. Jihad vs. McWorld. New York: Ballantine Books. 
Bhagwati, J. N. 2007. In Defense of Globalization. Reprint ed. New York: Oxford University Press.

Burawoy, M. 2000. Global Ethnography: Forces, Connections, and Imaginations in a Postmodern World. Berkeley: University of California Press.

Castells, M. 1996. The Information Age: Economy, Society, and Culture. Vol. 1. The Rise of the Network Society. Oxford: Blackwell.

Castells, M. 1997. The Information Age: Economy, Society, and Culture. Vol. 2. The Power of Identity. Oxford: Blackwell.

Castells, M. 1998. The Information Age: Economy, Society, and Culture. Vol. 3. End of Millennium. Oxford: Blackwell.

Castells, M. 2000. Materials for an Exploratory Theory of the Network Society. British Journal of Sociology 51 (1): 5-24.

Castells, M. 2003. Global Information Capitalism. In Held, D., and McGrew, A. (eds.), The Global Transformations Readers: An Introduction to the Globalization Debate. $2^{\text {nd }}$ ed. Cambridge, Oxford and Malden: Polity.

Castells, M. 2008. The New Public Sphere: Global Civil Society, Communication, Networks, and Global Governance. The Annals of the American Academy of Political Science 616 (1): 78-93.

Cerny, P. G. 1996. Globalization and Other Stories: The Search for a New Paradigm for International Relations. International Journal 51: 617-637.

Chase-Dunn, C. 1998. Global Formations: Structures of the World Economy. Lanham, MD: Rowman and Littlefield.

Delanty, G. 2009. The Cosmopolitan Imagination: The Renewal of Critical Social Theory. Cambridge: Cambridge University Press.

Giddens, A. 1990. The Consequences of Modernity. Stanford: Stanford University Press.

Gilpin, R., and Gilpin, J. M. 2001. Global Political Economy: Understanding the International Economic Order. Princeton, N.J.: Princeton University Press.

Hardt, M., and Negri, A. 2000. Empire. Cambridge, MA; London: Harvard University Press.

Hart-Landsberg, M. 2015. From the Claw to the Lion: A Critical Look at Capitalist Globalization. Critical Asian Studies 47 (1): 1-23.

Harvey, D. 1990. The Condition of Postmodernity: An Enquiry into the Origins of Cultural Change. Oxford: Blackwell.

Herman, E. S., and Chomsky, N. 2006. Manufacturing Consent: The Political Economy of the Mass Media. New York: Pantheon Books.

Hirst, P., and Thomson, G. 1996. Globalization in Question. Oxford: Blackwell Publisher Inc.

Hirst, P., and Thompson, G. 1999. Globalization in Question: The International Economy and the Possibilities of Governance. $2^{\text {nd }}$ ed. Cambridge: Polity Press.

Huntington, S. P. 1993. The Clash of Civilization? Foreign Affairs 72 (3): 22-49.

Huntington, S. P. 1997. The Clash of Civilizations and the Remaking of World Order. New York: Touchstone.

Idowu, A.-S., and Oladiti, A. A. 2016. The Forces of Globalization and the Arab Spring in Modern Libya. Journal of Globalization Studies 5 (2): 112-123.

Kaldor, M. 2003. Global Civil Society: An Answer to War. Cambridge: Polity Press.

Kellner, D. 2002. Globalization and the Postmodern Turn and Theorizing Globalization. URL: http://pages.gseis.ucla.edu/faculty/kellner/essays/globalizationpostmodernturn. 
Keohane, R. O., and Nye, Jr., J. S. 2000. Globalization: What's New? What's Not? (And So What?) Foreign Policy 118: 104-120.

Kim, H. J., and Sharman, J. C. 2014. Accounts and Accountability: Corruption, Human Rights, and Individual Accountability Norms. International Organization 68 (2): 417-448.

King, S. D. 2017. Grave New World: The End of Globalization, the Return of History. New Haven, CT: Yale University Press.

Livesey, F. 2017. From Global to Local: The Making of Things and the End of Globalization. New York: Patheton.

Mazlish, B. 2006. The New Global History. URL: http://web.mit.edu/newglobalhistory/ docs/mazlich-the-new-global-history.pdf.

McGrew, A. 1990. A Global Society. In Hall, S., Held, D., and McGrew, A. (eds.), Modernity and Its Futures (pp. 61-116). Cambridge: Polity Press.

Meyer, J. W., Boli, J., Thomas, G. M., and Ramirez, F. O. 1997. World Society and the Nation-State. American Journal of Sociology 103 (1): 144-181.

Milanovic, B. 2016. Global Inequality: A New Approach for the Age of Globalization. Cambridge, Massachusetts and London: Harvard University Press.

Mittelman, J. H. 2000. Globalization: An Ascendant Paradigm. URL: http://www.colorado. edu/ibs/PEC/gadconf/papers/mittelman.pdf.

Neubauer, D. 2014. The Rise of the Global Corporation. In Steger, M. B., Battersby, P., and Siracusa, J. M. (eds.), The Sage Handbook of Globalization (pp. 266-282). London: SAGE Publications.

Ordóñez, S., and Sánchez, C. 2016. Knowledge Capitalism, Globalization, and Hegemony: Toward a Socio-Spatial Approach. World Review of Political Economy 7 (1): 4-28.

Pieterse, J. N. 2004. Globalization or Empire? New York and London: Routledge.

Pieterse, J. N. 2015. Globalization and Culture. $3^{\text {rd }}$ ed. Lanham: Rowman \& Littlefield.

Pieterse, J. N. 2017. Multipolar Globalization: Emerging Economies and Development. $1^{\text {st }}$ ed. London: Routledge.

Prempeh, O. K. 2004. Anti-Globalization Forces, the Politics of Resistance, and Africa: Promises and Perils. Journal of Black Studies 34 (4): 580-598.

Rajgopal, S. S. 2002. Reclaiming Democracy? The Anti-Globalization Movement in South Asia. Feminist Review 70: 134-137.

Ramirez, F. O., Soysal, Y., and Shanahan, S. 1997. The Changing Logic of Political Citizenship: Cross-National Acquisition of Women's Suffrage Rights, 1890 to 1990. American Sociological Review 62: 735-745.

Ritzer, G. 1993. The McDonaldization of Society: An Investigation into the Changing Character of Contemporary Social Life. Los Angeles, CA: Pine Forge Press.

Robertson, R. 1992. Globalization: Social Theory and Global Culture. London: Sage.

Robertson, R. 1995. Glocalization: Time-Space and Homogeneity-Heterogeneity. In Featherstone, M., Lash, S., and Robertson, R. (eds.), Global Modernities (pp. 25-44). Thousand Oaks, CA: Sage.

Robinson, W. I. 2004. A Theory of Global Capitalism. Baltimore, MD: The Johns Hopkins University Press.

Rosenau, J. N. 1997. Along the Domestic-Foreign Frontier: Exploring Governance in a Turbulent World. Cambridge: Cambridge University Press. 
Rowe, W., and Schelling, V. 1991. Memory and Modernity: Popular Culture in Latin America. London: Verso.

Sassen, S. 2003. Globalization or Denationalization? Review of International Political Economy 10 (1): 1-22.

Sassen, S. 2006. Territory, Authority, Rights: From Medieval to Global Assemblages. Princeton, N.J.: Princeton University Press.

Schattle, H. 2012. Globalization and Citizenship. Lanham, MD: Rowman \& Littlefield Publishers.

Scholte, J. A. 1995. Globalisation and Modernity. Paper presented at the International Studies Association Convention, San Diego, 15-20 April 1995.

Steger, M. B. 2008. The Rise of the Global Imaginary: Political Ideologies from the French Revolution to the Global War on Terror. Oxford: Oxford University Press.

Steger, M. B. 2009. Globalisms: The Great Ideological Struggle of the $21^{\text {st }}$ Century. $3^{\text {rd }}$ ed. Lanham, MD: Rowman \& Littlefield.

Steger, M. B. 2014. Globalization. The Encyclopedia of Political Thought. 1488-1499.

Steger, M. B., and Wilson, E. K. 2012. Anti-Globalization or Alter-Globalization? Mapping the Political Ideology of the Global Justice Movement. International Studies. Quarterly 56 (3): 439-454.

Steger, M. B. and James, P. 2013. Levels of Subjective Globalization: Ideologies, Imaginaries, Ontologies. Perspectives on Global Development and Technology 12 (1-2): 17-40.

Stiglitz, J. E. 2002. Globalization and its Discontents. New York: W.W. Norton.

Strange, S. 1996. The Retreat of the State: The Diffusion of Power in the World Economy. Cambridge: Cambridge University Press.

Talbott, S. P. 1996. Global Localization of the World Market: Case Study of Mcdonald's in Moscow. Sociale Wetenschappen 31-44.

Thakur, R., and Weiss, T. G. 2015. Framing Global Governance, Five Gaps. In Steger, M. B. (ed.), The Global Studies Reader (pp. 27-40). New York: Oxford University Press.

Tomlinson, J. 1999. Globalization and Culture. Chicago: Chicago University Press.

Truevtsev, K. 2016. Globalization as a Political Process. Journal of Globalization Studies 7 (1): 66-86.

Wagnleitner, R. 1994. Coca-Colonization and the Cold War: The Cultural Mission of the United States in Austria after the Second World War. Chapel Hill \& London: The University of North Carolina Press.

Wallerstein, I. 2000. Globalization or the Age of Transition?: A Long-Term View of the Trajectory of the World-System. International Sociology 15 (2): 249-265.

Waltz, K. N. 1999. Globalization and Governance. PS: Political Science \& Politics 23: 693-700.

Weiss, L. 1998. The Myth of the Powerless State: Governing the Economy in a Global Era. Ithaca, NY: Cornell University Press.

Young, O. 1989. The Politics of International Regime Formation: Managing Natural Resources and the Environment. International Organization 43 (3): 349-375. 